\title{
Grb10 characterization in bovine cumulus oocyte complexes from different follicle sizes
}

\author{
Caracterização do Grb10 em complexos cumulus-oócito oriundos de \\ folículos bovino de diferentes tamanhos
}

\author{
Paulo Roberto Antunes da Rosa ${ }^{I^{*}}$ Rodrigo Camponogara Bohrer ${ }^{\mathrm{I}}$ Charles Alencar Ludke \\ Matheus Pedroti De Cesaro ${ }^{I}$ Gabriel Ribas Pereira ${ }^{I}$ Rafael Gianela MondadoriII \\ Alfredo Quites Antoniazzi ${ }^{I}$ Paulo Bayard Dias Gonçalves ${ }^{\mathrm{I}}$
}

\begin{abstract}
The objective of this study was to investigate the $m R N A$ expression and protein localization of Grb10 gene in bovine cumulus-oocyte complexes (COCs) from different follicle sizes. Firstly, it was investigated the $m R N A$ expression to correlate with maturation rates. COCs from follicles at 1-3, 4-6, 6-8 and $>8 \mathrm{~mm}$ were used to evaluate Grb10 gene expression by $q R T-P C R$ assay and nuclear maturation rates. It was observed that more competent oocytes (from follicles at $6-8$ and $>8 \mathrm{~mm} ; P<0.05$ ), had lower Grb10 mRNA expression levels when compared to the oocytes from follicles at 1-3 and 4-6mm $(P<0.05)$. After it was performed an immunofluorescence analysis in COCs from different follicle sizes (1-3, 4-6, 6-8 and >8mm) to investigate Grb10 protein localization. Samples were incubated with primary antibody: Polyclonal rabbit anti-Grb10 (1:100). Primary antibody was detected using goat anti-rabbit IgG antibody conjugated with Alexa Fluor 488 (1:500). Positive fluorescence signal was detected in all analyzed samples but less evident in COCs from largest follicles. These results characterized Grb10 gene in bovine COC and provide evidences for its involvement during oocyte molecular maturation.
\end{abstract}

Key words: $m R N A$, protein, maturation, oocyte, Grb10.

\section{RESUMO}

O objetivo deste estudo foi investigar a expressão de RNAm e a localização da proteína Grb10 em complexos cumulusoócito (CCO), oriundos de folículos bovinos em diferentes fases de desenvolvimento. Primeiramente, foi investigada a expressão de $R N A m$ e relacionada com as taxas de maturação. CCOs oriundos de folículos com diâmetro de 1-3, 4-6, 6-8 e >8mm foram utilizados para avaliar a expressão de RNAm por PCR em tempo real e para analisar os estádios de maturação nuclear. Foi observado que os oócitos mais competentes para a progressão meiótica (oriundos de folículos com diâmetro de $6-8$ e $>8 \mathrm{~mm} ; \mathrm{P}<0.05)$ tiveram menor expressão de RNAm para Grb10, quando comparados aos CCOs oriundos de folículos com 1-3 e 4-6mm $(P<0.05)$. Posteriormente, foi realizada a técnica de imunofluorescência em CCOs oriundos de foliculos de diferentes tamanhos (1-3, 4-6, 6-8 e >8mm) para investigar a localização da proteina Grb10. As amostras foram incubadas com o anticorpo primário: anti-Grb10 policlonal, produzido em coelho (1:100). O anticorpo primário foi detectado utilizando um anticorpo secundário, IgG anti-coelho, produzido em cabra, conjugado com Alexa Fluor 488 (1:500). A fluorescência foi detectada em todas as amostras analisadas, porém, menos evidente nos CCOs oriundos dos folículos maiores. Os resultados apresentados neste estudo caracterizam o gene Grb10 em CCOs de bovinos e fornecem evidências do seu envolvimento na maturação molecular do oócito.

Palavras-chave: RNAm, proteina, maturação, oócito, Grb10.

\section{INTRODUCTION}

The growth factor receptor-bound protein $10(\mathrm{Grb} 10)$ is a member of the Grb7 family adaptor molecules that includes Grb10, Grb14 and Grb7 proteins. The structure of the Grb7 family of the adaptor protein is composite by a carboxylterminal src-homology 2 (SH2), GM domain and a proline-rich region. The GM domain region has a sequence homology from all Grb7 family proteins that contains a pleckstrin homology $(\mathrm{PH})$ domain, a Ras-association domain and a functional region called BPS, which is localized between the PH and $\mathrm{SH} 2$ domains. The high sequence homology and the

'Laboratório de Biotecnologia e Reprodução Animal (BioRep), Departamento de Clínica de Grandes Animais, Hospital Veterinário Universitário (HVU), Universidade Federal de Santa Maria (UFSM), Campus Camobi, 97105-900, Santa Maria, RS, Brasil. E-mail: robertoadr@yahoo.com.br.*Corresponding author.

ILLaboratório de Reprodução Animal (ReproPEL), Universidade Federal de Pelotas (UFPel), Pelotas, RS, Brasil. Received 05.15.14 Approved 09.26.14 Returned by the author 01.08.15 CR-2014-0762.R1 
conservative molecular architecture among the Grb7 family members allow them to participate in multiple cellular signal transduction pathways (HAN et al., 2001; HOLT \& SIDDLE, 2005).

The Grb10 protein is known to have different isoforms that are responsible for binding several trans-membrane tyrosine-kinase receptors, including the insulin receptor (IR), the insulin-like growth factor receptor (IGF-IR) and the epidermal growth factor receptor (EGFR) (HOLT \& SIDDLE, 2005). Tyrosine kinase receptor's residues are autophosphorylated upon binding to growth factors in their extracellular portion. Grb10 protein binding sites are BPS and $\mathrm{SH} 2$ domains, which bind to phosphorylated tyrosine kinase receptors. This mechanism inhibit Phosphatidylinositide 3-kinase (PI3K) and Mitogen-activated protein kinase (MAPK) pathways, which trigger intracellular changes in gene expression pattern related to metabolism control and cell proliferation (LIM et al., 2004). Interestingly, some studies about insulin-responsive tissue have shown the Grb10 protein involvement in tumors responsive to IGF-I, insulin metabolism, diabetes and growth abnormalities (HOLT et al., 2009; LI et al., 2013).

Studies performed in HeLa human cell line, using small interfering (si)RNA, revealed that knockdown of Grb10 gene enhances IGF-I DNA synthesis by activating Akt/PKB (also called protein kinase B) and ERK1/2 (DUFRESNE \& SMITH, 2005). Similarly, in rats, primary adipocyte culture overexpressing Grb10 inhibits insulin stimulation of MAPK phosphorylation, suggesting that endogenous Grb10 inhibits insulin signaling (LANGLAIS et al., 2004).

The oocyte maturation, including cytoplasmic and molecular events, occurs gradually and is synchronized with the follicular events (BEVERS et al., 1997). The relationship between follicular size and oocyte competence to undergo complete nuclear maturation has been well described in the cattle (LONERGAN et al., 1994; ARLOTTO et al., 1996).

Local growth factors such as IGF-I, EGF and fibroblast growth factor 10 (FGF10) added into the maturation medium improves the oocyte maturation, resulting in an increase in the in vitro blastocyst rate (WANG et al., 2009; ZHANG et al., 2010). Consequently, tyrosine kinase receptors have important functions on oocyte molecular maturation during follicular development (YAMASHITA \& SHIMADA, 2012; YAN et al., 2012). In addition, some events during bovine oocyte maturation including mitogenesis and metabolism are regulated by cytosolic kinase activity such as MAPK also called "extracellular signal-regulated kinase" (ERK) and maturation promoting factor (MPF).

To date, the presence of the Grb10 mRNA and protein have not been investigated in mammalian oocytes, despite the importance of growth factors that bind receptors with tyrosine kinase activity during mammalian oocyte molecular maturation. For this reason, the hypothesis is that Gbr10 is present in COCs and may have important role in oocyte molecular maturation. Thus, the objective of this study was to evaluate the Grb10 mRNA and protein expression in bovine COCs from follicles at different growing stages.

\section{MATERIALS AND METHODS}

All procedures involving COCs were conducted in vitro with bovine ovaries collected in a local abattoir.

Assessment of oocyte nuclear maturation

The COCs from different follicular size (1$3,4-6,6-8$ and $>8 \mathrm{~mm}$ ) were cultured in a maturation medium for $20 \mathrm{~h}$ at $39^{\circ} \mathrm{C}$ in an atmosphere of $5 \%$ $\mathrm{CO} 2$ in air with saturated humidity as described by STEFANELLO et al. (2006). Then, the cumulus cells were removed by vortexing and oocytes were fixed in $4 \%$ paraformaldehyde during $15 \mathrm{~min}$ and transferred to $0.5 \%$ Triton-X-100. After, oocytes were stained with $10 \mu \mathrm{g} / \mathrm{ml}$ bisbezimide (Hoechst 33342) and analyzed under a fluorescence microscope. Oocyte maturation status was classified as immature [germinal vesicle $(\mathrm{GV})$, germinal vesicle breakdown (GVBD), metaphase-I (M-I)] and mature [anaphase-I (AI), telophase-I (TI), and metaphase-II (M-II)].

Ribonucleic acid extraction and real-time RT-PCR

Total RNA was extracted from samples of 30-50 COCs using Trizol protocol according to the manufacturer's instructions and was quantified by absorbance at $260 \mathrm{~nm}$ using a spectrophotometer (NanoDrop, Thermo Fischer Scientific Inc., Waltham, MA). The total RNA integrity was verified electrophoretically by ethidium bromide staining and purity was determined by absorption rate relationship of OD260/280. Only total RNA samples containing values $>1.7$ were used in this experiment.

Total RNA was first treated with $0.2 \mathrm{U}$ DNase (Promega, Madison, WI) at $37^{\circ} \mathrm{C}$ for $30 \mathrm{~min}$ to digest DNA, followed by heating to $65^{\circ} \mathrm{C}$ for $3 \mathrm{~min}$. The RNA was reverse transcribed (RT) in the 
presence of $1 \mu \mathrm{M}$ oligo (dT) primer, $4 \mathrm{U}$ Omniscript RTase (Omniscript RT Kit; Qiagen), $0.5 \mu \mathrm{M}$ dideoxynucleotide triphosphate (dNTP) mix, and $10 \mathrm{U}$ RNase inhibitor (Invitrogen) in a volume of $20 \mu \mathrm{L}$ at $37^{\circ} \mathrm{C}$ for $1 \mathrm{~h}$. The reaction was terminated by incubation at $93^{\circ} \mathrm{C}$ for $5 \mathrm{~min}$.

The relative gene expression was assessed by real-time PCR (RT-PCR) using the StepOnePlus ${ }^{\mathrm{TM}}$ RT-PCR system (Applied Biosystems, Foster City, CA). All samples were analyzed in duplicate and each sample contained $12.5 \mu$ l of SYBR Green PCR Master Mix (Applied Biosystems), 8.5 $\mu$ l of $\mathrm{H}_{2} \mathrm{O}, 1 \mu \mathrm{l}$ of forward primer $(200 \mathrm{nM}), 1 \mu 1$ of reverse primer $(200 \mathrm{nM})$ and $2 \mu \mathrm{l}$ of cDNA. The reaction was carried out as following: $50^{\circ} \mathrm{C}$ for $2 \mathrm{~min}, 95^{\circ} \mathrm{C}$ for $10 \mathrm{~min}, 40$ cycles at $95^{\circ} \mathrm{C}$ for $15 \mathrm{sec}$ and $60^{\circ} \mathrm{C}$ for $1 \mathrm{~min}$. Meltingcurve analyses were performed to verify product identity. The variability in the amount of mRNA was corrected by amplification of GAPDH housekeeping gene, and relative expression was performed as recommended by PFAFFL (2001). The primers for Grb10 (F- GGAGATTCTGGCAGACATGA and R- TAATCCCAGGTGTGGGTGAT) and GAPDH (F- GATTGTCAGCAATGCCTCCT and R- GGTCATAAGTCCCTCCACGA) were designed using Primer Express software v 3.3 (Applied Biosystems) and synthesized by Invitrogen.

\section{Immunofluorescence assessment}

Bovine follicles at different size 1-3, 4-6, 6-8 and $>8 \mathrm{~mm}$ were isolated from the ovaries and fixed into a $4 \%$ paraformaldehyde solution at $4{ }^{\circ} \mathrm{C}$ for $12 \mathrm{~h}$ and paraffin embedded for further evaluation of Grb10 protein. Histological sections with $5 \mu \mathrm{m}$ in thickness were prepared to perform immunofluorescence analysis. Slides were deparaffinized using xylene for $15 \mathrm{~min}$, rehydrated through a graded ethanol series (one time for $5 \mathrm{~min}$ in each $100 \%, 90 \%, 80 \%$, $70 \%$ and $50 \%$ dilution), and rinsed for $15 \mathrm{~min}$ in distilled water. Endogenous peroxidase activity was then blocked for $20 \mathrm{~min}$ in hydrogen peroxide $0.3 \%$ and washed three times in PBS for 5min. After washing, the slides were carefully blotted using a PAP pen (Vector Laboratory, Burlingame, CA) around the tissue. A blocking solution (PBS with $3 \%$ of Bovine Serum Albumin and $0.2 \%$ Tween-20) was used to block non-specific sites during $2 \mathrm{~h}$ at room temperature in a humidified chamber. After washed three times in PBS(1X) for 5min, the primary antibody in the same blocking solution was used to incubate the primary Grb10 antibody (sc-1026; dilution 1:100; Santa Cruz Biotechnology, CA, USA) in a humidified chamber overnight at $5^{\circ} \mathrm{C}$. After this incubation, samples were washed three times in a PBS1X containing $0.2 \%$ Tween- 20 for $5 \mathrm{~min}$ before being incubated for $1 \mathrm{~h}$ at room temperature to a goat anti-rabbit IgG antibody conjugated with Alexa Fluor 488 (dilution 1:500; Invitrogen). Then, slides were washed three times in a $\operatorname{PBS}(1 \mathrm{X})$ containing $0.2 \%$ Tween-20 for $5 \mathrm{~min}$. Finally, to enable nuclear staining visualization, samples were incubated with $300 \mathrm{nM}$ of 4',6-diamidino-2-phenylindole (DAPI; Invitrogen) in PBS(1X) for $5 \mathrm{~min}$ at room temperature. Then, slides were mounted with a space between the coverslip, filled with $50 \mu$ d drop of Aqueous Mounting Medium (Fluoromount) and sealed with nail polish. Laserscanning confocal microscopy was performed using a Confocal Microscope Spectral FV1000 (Olympus). Laser scanning microscope was equipped with two lasers for the simultaneous excitation of Alexa Fluor 488 fluorescent for Grb10, and DAPI for DNA, with fluorescence excitation and emission of $495 / 518$ and $358 / 461 \mathrm{~nm}$, respectively. Image software FV-Viewer (Olympus) was used to obtain sample images.

\section{Statistical analysis}

The results of gene expression were compared by analysis of variance (PROC GLM; General Linear Models Procedure). When it was observed the treatment effect, the means between the different groups were compared using the multicomparison of means test least squares means (LSMEANS). All continuous variables were tested for normality with the support of the Shapiro-Wilk test and normalized when necessary according to each distribution. The analysis of the percentage of maturation in different groups was performed by chi-square test, using PROC CATMOD. The multi-comparison among the different groups was performed by means of contrasts. Analyses were performed using the statistical program SAS and adopted the significance level of $5 \%$. The results of gene expression were represented as mean \pm standard error of the mean for each replication and nuclear maturation were represented in percentage form.

\section{RESULTS}

Grb10 mRNA expression and nuclear maturation rates in COCs from follicles at different stages of development

Confirming previous studies (MARCHAL et al., 2002), the oocytes from follicles with 1-3 or $4-6 \mathrm{~mm}$ in diameter had lower $(\mathrm{P}<0.05)$ maturation rates than those from $6-8$ or $>8 \mathrm{~mm}$ in diameter (Figure 1A). Initially, Grb10 mRNA expression was evaluated 


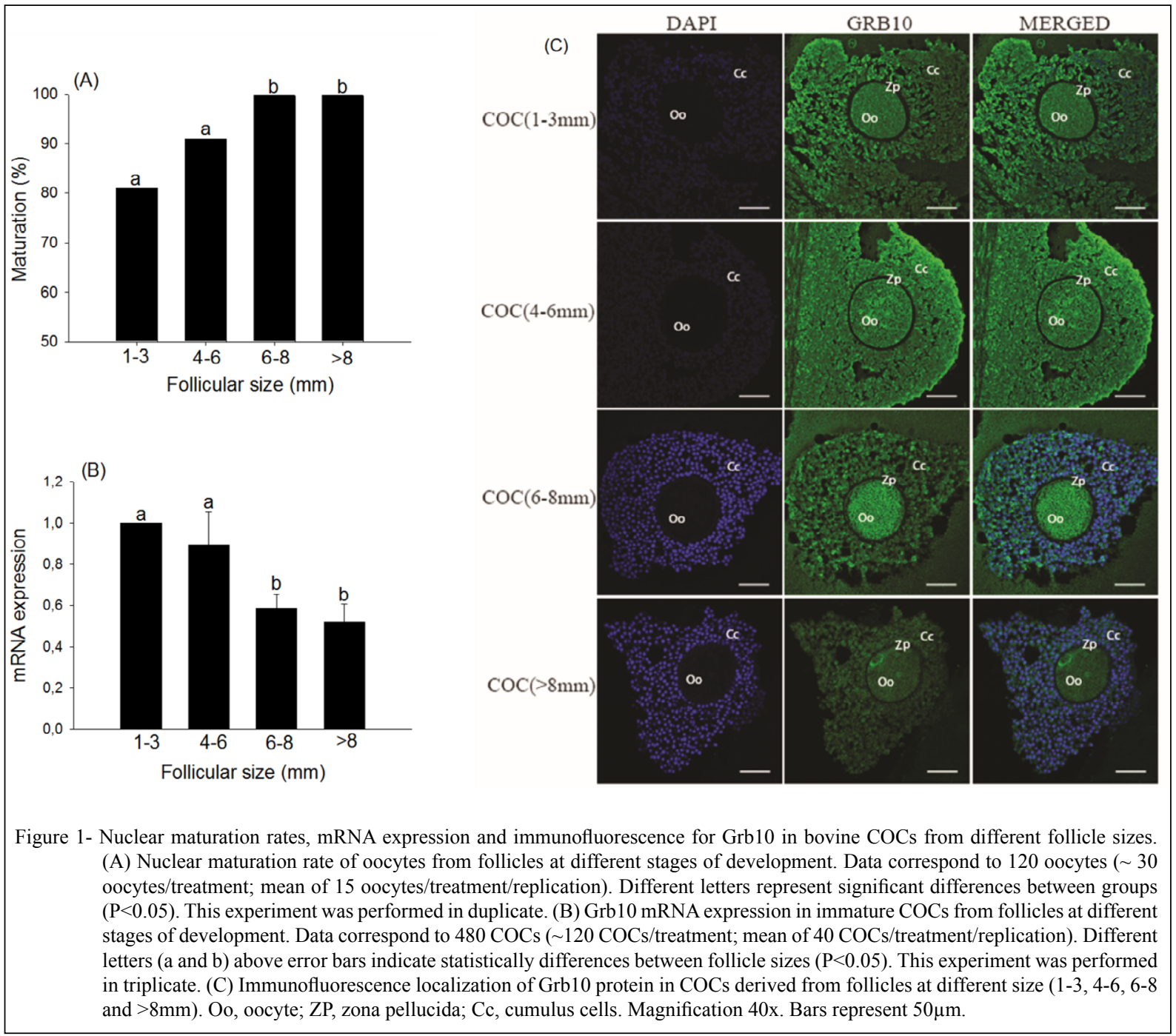

in isolated oocytes and cumulus cells by RT-PCR assay in order to validate the model. Considering that Grb10 mRNA was expressed in oocyte and cumulus cells, COCs from different follicle sizes were used in subsequent experiments. The results showed that Grb10 mRNA expression were higher $(\mathrm{P}<0.05)$ in COCs from follicles with 1-3 and 4-6mm in diameter than in COCs from follicles with $6-8$ and $>8 \mathrm{~mm}$ in diameter (Figure 1B). The Grb10 mRNA expression in COCs was inversely related to oocyte competence for meiotic progression to mature stage.

\section{Immunofluorescence staining of COCs}

Immunofluorescence confocal microscopy of COCs from follicles with different diameters revealed positive fluorescence signal for Grb10 protein in oocyte and cumulus cells of all COCs analyzed (Figure 1C). Interestingly, the positive fluorescence signaling was less evident in cumulus cells from follicles of $6-8$ and $>8 \mathrm{~mm}$ in diameter than those cells of $\leq 6 \mathrm{~mm}$ follicles (Figure 1C). The negative control samples cells were stained in the absence of primary antibody.

\section{DISCUSSION}

In this study, it was demonstrated for the first time the presence of Grb10 mRNA and protein expression in bovine COCs. The expression of Grb10 mRNA in COCs seems to be inversely correlated with oocyte capacity to progress to Metaphase II. Grb10 protein is clearly reduced in cumulus cells of follicle larger than $6 \mathrm{~mm}$ compared with those of smaller follicles. According to LONERGAN et al. (1994), oocyte competence necessary to achieve embryo development increases proportionally to follicular 
size. For this reason, these results suggest that Grb10 is involved in acquisition of oocyte competence throughout antral follicle growth.

During follicular development, COCs undergo extensive proliferation and differentiation (ARMSTRONG et al., 1996). Grb10 seems to be involved in these two processes through interaction with tyrosine kinase receptors. In mouse embryonic fibroblast cell lines, IGF-I-mediated mitosis is inhibited by Grb10 (MORRIONE et al., 1997). In addition, Grb10 over-expression inhibits insulinstimulated glycogen synthesis in rat hepatocytes (MOUNIER et al., 2001). Taken together with the results of this study, we suggest that in bovine COCs Grb10 is probably involved in proliferative events controlling tyrosine kinase receptors activity. However, more studies should be performed to confirm the functional role of this gene.

Grb10 plays a pivotal role in multiple intracellular transduction pathways after binding to activated tyrosine kinase receptors (LUCASFERNANDEZ et al., 2008). For the success of maturation process, changes in transcriptional activity are needed for oocyte fertilization and early embryonic development. In this context, some genes increase their expression levels in mammalian COCs during follicular development while other decrease to obtain optimal oocyte molecular maturation (MAMO et al., 2011). This previous data associated with the decrease in the Grb10 mRNA in COCs from larger follicles $(>6 \mathrm{~mm})$ showed in our results, suggest a new insight for future studies focusing on the capacity of the Grb10 to modulate some signal transduction pathways.

Mammalian cumulus cells have important functions during oocyte maturation process such as: reduction in steroidogenesis and increase in hyaluronic acid production for cumulus expansion (EPPIG, 2001). To achieve these functions, some genes must be down-regulated, such as Nuclear receptor-interacting protein 1 (Nrip1) (SUGIURA et al., 2010). Previous studies showed that Nrip1 plays an important role in controlling lipid and glucose metabolism (ROSELL et al., 2010). In agreement, a study using knockout mice with a disruption of the Grb10 gene was found to improve insulin sensitivity and to reduce adiposity (SMITH et al., 2007). An association of Nrip1 and Grb10 has not been described yet.

Grb10 protein seems to be related as an imprinted gene growth suppressor in mice and rats. Also, the disruption of Grb10 maternal allele gene caused an overgrowth in mice at birth (CHARALAMBOUS et al., 2003) and in adult rats (WANG et al., 2007). Therefore, this failure in embryonic development may be due to lack of accumulated Grb10 mRNA and protein in female gamete. RNAs and proteins synthesized and stored by the oocyte are important to maintain early embryonic development (LONERGAN et al., 1998). Taken together, previous data and the characterization of Grb10 mRNA and protein in bovine COCs, contribute to study some development anomalies in in vitro embryo production.

In conclusion, it was demonstrated differential expression of Grb10 mRNA and protein localization in bovine COCs from follicles at different developmental stages. These characterization data is a part of a study that will provide new important data and some intracellular molecular pathways probably involved in oocyte maturation.

\section{ACKNOWLEDGMENTS}

The authors would like to thanks Frigorífico Silva for the donation of bovine ovaries used in this research and to Coordenação de Aperfeiçoamento de Pessoal de Nível Superior (CAPES), Conselho Nacional de Desenvolvimento Científico e Tecnológico (CNPq) and Fundação de Amparo à Pesquisa do Estado do Rio Grande do Sul (FAPERGS) for financial support.

\section{REFERENCES}

ARLOTTO, T. et al. Aspects of follicle and oocyte stage that affect in vitro maturation and development of bovine oocytes. Theriogenology, v.45, n.5, p.943-56, 1996. Available from: $<$ http://www.ncbi.nlm.nih.gov/entrez/query.fcgi?cmd=Retrieve \&d $\mathrm{b}=$ PubMed\&dopt $=$ Citation\&list_uids $=16727855>$. Accessed: Apr. 15, 2011. doi:10.1016/0093-691X(96)00024-6.

ARMSTRONG, D.T. et al. Differential effects of insulin-like growth factor-I and follicle-stimulating hormone on proliferation and differentiation of bovine cumulus cells and granulosa cells. Biology of Reproduction, v.54, n.2, p.331-338, 1996. Available from: $<$ http://www.ncbi.nlm.nih.gov/entrez/query.fcgi?cmd=Retrieve\&d $\mathrm{b}=$ PubMed\&dopt $=$ Citation\&list_uids $=8788183>$. Accessed: May. 10, 2011. doi: 10.1095/biolreprod54.2.331.

BEVERS, M.M. et al. Regulation and modulation of oocyte maturation in the bovine. Theriogenology, v.47, n.1, p.13-22, 1997. Available from: <http://www.sciencedirect.com/science/ article/B6TCM-3RHM8H2-42/2/45251c1f26df38912537a 8 e5flc8496e>. Accessed: Jan. 25, 2010. doi: 10.1016/S0093691X(96)00335-4.

CHARALAMBOUS, M., et al. Disruption of the imprinted Grb10 gene leads to disproportionate overgrowth by an Igf2-independent mechanism. Proceedings of the National Academy of Sciences of the United States of America, v.100, n.14, p.8292-8297, 2003. Available from: <http://www.pnas.org/content/100/14/8292. abstract $>$. Accessed: Apr. 15, 2011. doi: 10.1073/pnas. 1532175100.

DUFRESNE, A.M.; SMITH, R.J. The adapter protein GRB10 is an endogenous negative regulator of insulin-like growth factor signaling. 
Endocrinology, v.146, n.10, p.4399-4409, 2005. Available from: $<$ http://endo.endojournals.org/cgi/content/abstract/146/10/4399>. Accessed: feb. 10, 2011. doi: 10.1210/en.2005-0150.

EPPIG, J. Oocyte control of ovarian follicular development and function in mammals. Reproduction, v.122, n.6, p.829-838, 2001. Available from: <http://www.reproduction-online.org/cgi/content/ abstract/122/6/829>. Acessed: Dec. 05, 2010. doi: 10.1530/ rep.0.1220829.

HAN, D.C. et al. The Grb7 family proteins: structure, interactions with other signaling molecules and potential cellular functions. Oncogene, v.20, n.44, p.6315-6321, 2001. Available from: $<$ http:// www.ncbi.nlm.nih.gov/entrez/query.fcgi? cmd $=$ Retrieve $\& d b=P u$ bMed\&dopt $=$ Citation\&list_uids $=11607834>$. Accessed: Oct. 08, 2010. doi: 10.1038/sj.onc. 1204775 .

HOLT, L.J. et al. Dual ablation of Grb10 and Grb14 in mice reveals their combined role in regulation of insulin signaling and glucose homeostasis. Molecular Endocrinology, v.23, n.9, p.1406-1414, 2009. Available from: <http://mend.endojournals.org/cgi/content/ abstract/23/9/1406>. Accessed: Jan. 11, 2011. doi: 10.1210/ me.2008-0386

HOLT, L.J.; SIDDLE, K. Grb10 and Grb14: enigmatic regulators of insulin action--and more? Biochemical Journal, v.388, n.2, p.393-406, 2005. Available from: <http://www.biochemj.org/ bj/388/bj3880393.htm>. Accessed: Oct. 21, 2010. doi: 10.1042/ bj20050216.

LANGLAIS, P. et al. Negative regulation of insulin-stimulated mitogen-activated protein kinase signaling by Grb10. Molecular Endocrinology, v.18, n.2, p.350-358, 2004. Available from: $<$ http://mend.endojournals.org/cgi/content/abstract/18/2/350 $>$. Accessed: Sep. 29, 2010. doi: 10.1210/me.2003-0117.

LI, L. et al. Growth receptor binding protein 10 inhibits glucosestimulated insulin release from pancreatic beta-cells associated with suppression of the insulin/insulin-like growth factor-1 signalling pathway. Clinical and Experimental Pharmacology Physiology, v.40, n.12, p.841-847, 2013. Available from: <http:// www.ncbi.nlm.nih.gov/pubmed/23937793>. Accessed: Mar. 15, 2014. doi: 10.1111/1440-1681.12160.

LIM, M. A., et al. Grb10: more than a simple adaptor protein. Frontiers in Bioscience, v.9, p.387-403, 2004. Available from: <http://www. ncbi.nlm.nih.gov/entrez/query.fcgi? $\mathrm{cmd}=$ Retrieve $\& \mathrm{db}=\mathrm{PubMed} \& \mathrm{do}$ $\mathrm{pt}=$ Citation\&list_uids $=14766376>$. Accessed: Apr. 15, 2011.

LONERGAN, P. et al. Effect of protein synthesis inhibition before or during in vitro maturation on subsequent development of bovine oocytes. Theriogenology, v.50, n.3, p.417-431, 1998. Available from: <http://www.ncbi.nlm.nih.gov/entrez/query.fcgi?cmd=Retrie ve $\& \mathrm{db}=$ PubMed $\&$ dopt $=$ Citation\&list_uids $=10732135>$. Accessed: Aug. 12, 2011. doi:10.1016/S0093-691X(98)00149-6.

LONERGAN, P. et al. Effect of follicle size on bovine oocyte quality and developmental competence following maturation, fertilization, and culture in vitro. Molecular Reproduction and Development, v.37, n.1, p.48-53, 1994. Available from: <http:// www.ncbi.nlm.nih.gov/entrez/query.fcgi? $\mathrm{cmd}=$ Retrieve $\& \mathrm{db}=\mathrm{Pu}$ bMed \&dopt $=$ Citation $\&$ list_uids $=8129930>$. Accessed: Apr. 15, 2009. doi: $10.1002 / \mathrm{mrd} .1080370107$.

LUCAS-FERNANDEZ, E., et al. Genomic organization and control of the grb7 gene family. Current Genomics, v.9, n.1, p.60-68, 2008. Available from: <http://www.ncbi.nlm.nih. gov/entrez/query.fcgi? $\mathrm{cmd}=$ Retrieve $\& \mathrm{db}=$ PubMed $\&$ dopt $=\mathrm{C}$ itation\&list_uids $=19424485>$. Accessed: Mar. 15, 2011. doi: $10.2174 / 138920208783884847$.

MAMO, S. et al. Sequential analysis of global gene expression profiles in immature and in vitro matured bovine oocytes: potential molecular markers of oocyte maturation. BMC Genomics, v.12, n.1, p.151, 2011. Available from: <http://www.biomedcentral. com/1471-2164/12/151>. Accessed: Jun. 02, 2011. doi: $10.1186 / 1471-2164-12-151$.

MARCHAL, R. et al. Effect of follicular size on meiotic and developmental competence of porcine oocytes. Theriogenology, v.57, n.5, p.1523-1532, 2002. Available from: <http://www.ncbi. nlm.nih.gov/entrez/query.fcgi? $\mathrm{cmd}=$ Retrieve $\& \mathrm{db}=$ PubMed\&dop $\mathrm{t}=$ Citation\&list uids $=12054210>$. Accessed: Apr. 12, 2010. Doi: 10.1016/S0093-691X(02)00655-6.

MORRIONE, A. et al. The role of mGrb10 $\alpha$ in insulin-like growth factor I-mediated growth. Journal of Biological Chemistry, v.272, n.42, p.26382-26387, 1997. Available from: <http://www. jbc.org/content/272/42/26382.abstract>. Accessed: Jun. 11, 2011. doi: $10.1074 / \mathrm{jbc} .272 .42 .26382$.

MOUNIER, C. et al. Specific inhibition by hGRB10zeta of insulin-induced glycogen synthase activation: evidence for a novel signaling pathway. Molecular and Cellular Endocrinology, v.173, n.1-2, p.15-27, 2001. Available from: <http://www.ncbi. nlm.nih.gov/entrez/query.fcgi?cmd=Retrieve \&db=PubMed\&d opt $=$ Citation\&list_uids $=11223174>$. Accessed: Apr. 12, 2010. doi:10.1016/S0303-7207(00)00439-1.

PFAFFL, M.W. A new mathematical model for relative quantification in real-time RT-PCR. Nucleic Acids Research, v.29, n.9, p.e45, 2001. Available from: <http://www.ncbi.nlm.nih. gov/entrez/query.fcgi? $\mathrm{cmd}=$ Retrieve $\& \mathrm{db}=$ PubMed\&dopt $=$ Citatio n\&list_uids $=11328886>$. Accessed: Apr. 12, 2010. doi: 10.1093/ nar/29.9.e45.

ROSELL, M. et al. Role of nuclear receptor corepressor RIP140 in metabolic syndrome. Biochimica et Biophysica Acta, v.1812, n.8, p.919-928, 2010. Available from: <http://www.ncbi.nlm.nih. gov/entrez/query.fcgi? $\mathrm{cmd}=$ Retrieve $\& \mathrm{db}=$ PubMed $\& d o p t=$ Citatio n\&list_uids $=21193034>$. Accessed: Apr. 15, 2010. doi: 10.1016/j. bbadis.2010.12.016.

SMITH, F.M. et al. Mice with a disruption of the imprinted Grb10 gene exhibit altered body composition, glucose homeostasis, and insulin signaling during postnatal life. Molecular and Cellular Biology, v.27, n.16, p.5871-5886, 2007. Available from: <http:// mcb.asm.org/cgi/content/abstract/27/16/5871>. Accessed: Apr. 15, 2010. doi: $10.1128 / \mathrm{mcb} .02087-06$.

STEFANELLO, J.R. et al. Effect of angiotensin II with follicle cells and insulin-like growth factor-I or insulin on bovine oocyte maturation and embryo development. Theriogenology, v.66, n.9, p.2068-2076, 2006. Available from: <http://www.ncbi.nlm.nih. gov/entrez/query.fcgi? $\mathrm{cmd}=$ Retrieve $\& \mathrm{db}=$ PubMed $\& \mathrm{dopt}=$ Citatio n\&list_uids $=16889824>$. Accessed: Jun. 20, 2010. doi:10.1016/j. theriogenology.2006.06.005.

SUGIURA, K. et al. Estrogen promotes the development of mouse cumulus cells in coordination with oocyte-derived GDF9 and BMP15. Molecular Endocrinology, v.24, n.12, p.2303-2314, 2010. Available from: <http://www.ncbi.nlm.nih.gov/entrez/ 
query.fcgi? $\mathrm{cmd}=$ Retrieve $\& \mathrm{db}=$ PubMed $\&$ dopt $=$ Citation $\&$ list uids $=21047911>$. Accessed: Jan. 15, 2011. doi: 10.1210/me.20100260 .

WANG, L.M. et al. Expression of IGF receptors and its ligands in bovine oocytes and preimplantation embryos. Animal Reproduction Science, v.114, n.1, p.99-108, 2009. Available from: <http://linkinghub.elsevier.com/retrieve/pii/S0378432008 004041? showall=true $>$. Accessed: Jan. 15, 2011. doi:10.1016/j. anireprosci.2008.09.019.

WANG, L., et al. Peripheral Disruption of the Grb10 Gene Enhances Insulin Signaling and Sensitivity In Vivo. Molecular and Cellular Biology, v.27, n.18, p.6497-6505, 2007. Avalaible from: <http:// mcb.asm.org/cgi/content/abstract/27/18/6497>. Accessed: Apr. 15, 2011. doi: $10.1128 / \mathrm{mcb} .00679-07$.

YAMASHITA, Y.; SHIMADA, M. The release of EGF domain from EGF-like factors by a specific cleavage enzyme activates the
EGFR-MAPK3/1 pathway in both granulosa cells and cumulus cells during the ovulation process. Jornal of Reproduction and Development, v.58, n.5, p.510-514, 2012. Available from: <http:// www.ncbi.nlm.nih.gov/pubmed/23124701>. Accessed: Nov. 22, 2013. doi: DN/JST.JSTAGE/jrd/2012-056.

YAN, L. et al. Vascular endothelial growth factor-induced expression of its receptors and activation of the MAPK signaling pathway during ovine oocyte maturation in vitro. Theriogenology, v.78, n.6, p.1350-1360, 2012. Available from: <http://www.ncbi. nlm.nih.gov/pubmed/22898011>. Accessed: Nov. 22, 2013. doi: 10.1016/j.theriogenology.2012.06.001S0093-691X(12)00328-7.

ZHANG, K. et al. Fibroblast growth factor-10 enhances bovine oocyte maturation and developmental competence in vitro. Reproduction, v.140, n.6, p.815-826, 2010. Available from: $<$ http://www.ncbi.nlm.nih.gov/entrez/query.fcgi?cmd=Retrieve \&d $\mathrm{b}=$ PubMed\&dopt $=$ Citation\&list uids $=20876224>$. Accessed: Apr. 15, 2011. doi: 10.1530/REP-10-0190. 